\title{
Effect of oestrogen antisera early in gestation on pregnancy maintenance in the pig
}

\author{
H. A. Robertson, R. J. Dwyer and G. J. King* \\ Animal Research Institute, Ottawa, Canada K1A OC6 and \\ *Department of Animal and Poultry Science, University of Guelph, Guelph, Canada, N1G 2W1
}

Summary. Injection of antisera to oestradiol- $17 \beta$ and to oestrone from Days 10 to 21 of pregnancy had no effect on the maintenance of the corpora lutea or the initiation of placental attachment in the pig.

\section{Introduction}

The observation that pig blastocysts are capable of synthesizing oestrogens in vitro from Day 12 of gestation (Perry, Heap \& Amoroso, 1973; Perry, Heap, Burton \& Gadsby, 1976) and the detection of this oestrogen in plasma as oestrone sulphate as early as Days 16-17 of pregnancy (Robertson \& King, 1974; Robertson, King \& Dyck, 1978) have led to the hypothesis that oestrogens of embryonic origin or their sulphates may act either as an embryonic signal for the maternal recognition of pregnancy by exerting a luteotrophic effect on the corpora lutea or may be involved in the initiation of placental attachment.

These prospective roles of unconjugated oestrogens have been investigated in this study by injecting pigs during early pregnancy with antisera to oestrone and to oestradiol-17 $\beta$.

\section{Materials and Methods}

\section{Animals}

Six multiparous Yorkshire sows weighing approximately $250 \mathrm{~kg}$ were bred on the first 2 days of behavioural oestrus ( 1 st day of oestrus = Day 0 ). On Day 8 or 9 a $3 \mathrm{~m}$ length of sterile polyethylene tubing (i.d. $0.76 \mathrm{~mm}$, o.d. $1.22 \mathrm{~mm}$ ) filled with heparinized saline $(100 \mathrm{i} . \mathrm{u} . / \mathrm{ml})$ was inserted aseptically, without anaesthesia, through a thin-walled 16-gauge needle along an ear vein for a minimum distance of $30-40 \mathrm{~cm}$ following the general procedure described by Anderson \& Elsley (1969). The animals were housed in standard farrowing crates. From Days 10 to 21 the animals received twice daily intramuscular injections of $0.5 \mathrm{ml}$ ovine antioestradiol $-17 \beta$ serum and $0.5 \mathrm{ml}$ ovine anti-oestrone serum in $5 \mathrm{ml}$ of $0.9 \%(\mathrm{w} / \mathrm{v})$ saline. On Day 22 the sows were killed, the reproductive tract removed and the embryos examined for normality of numbers and development.

\section{Histology}

Portions of the uterine horns from 4 sows were perfused with $6 \%$ paraformaldehyde. The perfused sections were opened after $30 \mathrm{~min}$ and blocks of tissue were removed from the region near the embryo. This material, and small cubes of corpora lutea from one of the sows, were fixed in glutaraldehyde, dehydrated, embedded in plastic and stained for light microscopy, employing the techniques described by King, Atkinson \& Robertson (1979). 


\section{Collection of blood samples}

Heparinized blood samples were collected daily by first withdrawing and discarding the heparinized saline in the cannula then withdrawing blood into another heparinized $10 \mathrm{ml}$ syringe. Samples were immediately cooled and centrifuged at $4^{\circ} \mathrm{C}$, and the plasma was frozen and stored at $-20^{\circ} \mathrm{C}$.

\section{Oestrogen antisera}

Antisera to 1,3,5-oestratrien-3,17-diol-6-O-carboxymethyloxime-BSA (Steraloids: $32 \mathrm{~mol}$ steroid/mol bovine serum albumin) (HAR- $\left.\mathrm{E}_{2}, 78-6\right)$ and to 1,3,5-oestratrien-3-ol-6,17-dione-6O-carboxymethyloxime-BSA (Steraloids: $22 \mathrm{~mol} \mathrm{steroid} / \mathrm{mol}$ bovine serum albumin) (HAR-E ${ }_{1}$, 78-5) were raised in sheep to a titre of $1: 840000$ and 1:560000 respectively. The antioestradiol- $17 \beta$ serum cross-reacted $5 \%$ with oestrone and $<1 \%$ with oestrone sulphate while the oestrone antiserum had cross-reactions of $2 \%$ with oestradiol $-17 \beta$ and $<1 \%$ with oestrone sulphate.

\section{Progesterone analysis}

The plasma progesterone concentration was determined in duplicate $1 \mathrm{ml}$ samples using a competitive binding assay (Neill, Johansson, Datta \& Knobil, 1967) as described by Robertson \& Sarda (1971) and Robertson (1972). The sensitivity was $0.1 \mathrm{ng} / \mathrm{ml}$ and the intra-assay coefficient of variation was $8 \%$.

\section{Plasma oestrone sulphate}

The concentration of oestrone sulphate in the plasma was measured at Day 22 by the method described by Robertson \& King (1974).

\section{Determination of anti-oestrogen titre in sow plasma}

The levels of unbound antibody to oestrone and to oestradiol-17 $\beta$ were determined sequentially in duplicate in all the available daily plasma samples from the 6 sows by estimating the

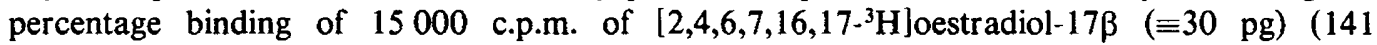
$\mathrm{Ci} / \mathrm{mmol}$, New England Nuclear) or $\left[2,4,6,7-{ }^{3} \mathrm{H}\right]$ oestrone $(\equiv 40 \mathrm{pg})(100 \mathrm{Ci} / \mathrm{mmol}$, New England Nuclear) to $25 \mu \mathrm{l}$ sow plasma at $4^{\circ} \mathrm{C}$. Radioactive purity was assessed by thin layer chromatography on silica gel. Unbound oestrogen was removed by the addition of dextrancharcoal as described by Robertson, Smeaton \& Durnford (1972). The titre was re-evaluated in one sow using 70000 c.p.m. of $\left[{ }^{3} \mathrm{H}\right]$ oestradiol- $17 \beta$ and $\left[{ }^{3} \mathrm{H}\right]$ oestrone.

\section{Results}

\section{Plasma progesterone}

Because of problems with the patency and breakage of the cannulae, plasma was not obtained from all sows each day. Plasma levels of progesterone before and during antiserum administration are shown in Text-fig. 1. The mean concentration appeared to decrease from 28 $\mathrm{ng} / \mathrm{ml}$ at Day 13 to $16.8 \mathrm{ng} / \mathrm{ml}$ by Day 22 . 


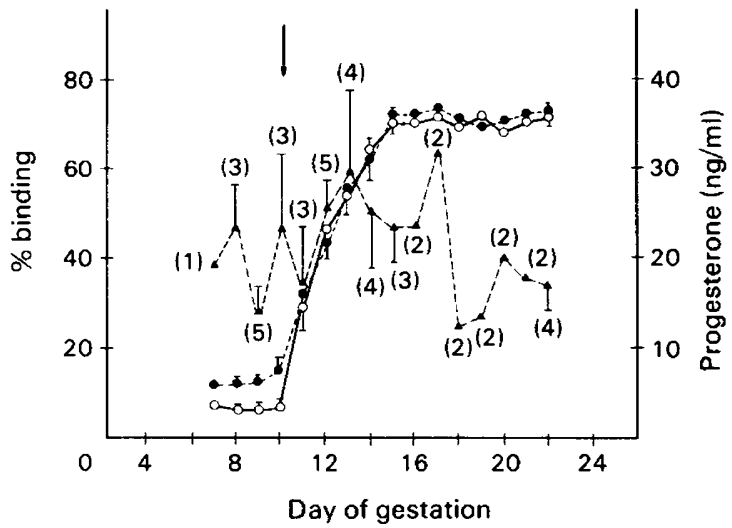

Text-fig. 1. Mean \pm s.e.m. percentage binding of 15000 c.p.m. $\left[{ }^{3} \mathrm{H}\right]$ oestradiol- $17 \beta(30 \mathrm{pg})(\odot)$ and $\left[{ }^{3} \mathrm{H}\right]$ loestrone $(40 \mathrm{pg})(\mathrm{O})$ to $25 \mu \mathrm{l}$ sow plasma at $4^{\circ} \mathrm{C}$ and mean \pm s.e.m. concentrations of plasma progesterone $(\boldsymbol{\Lambda})$ before and after the start (arrow) of treatment with oestrogen antisera. The numbers in parentheses indicate the number of animals at each point for the binding and progesterone determinations.

\section{Plasma oestrone sulphate}

The concentration of oestrone sulphate (as the unconjugated oestrone equivalent) in the plasma at Day 22 ranged from 300 to $760 \mathrm{ng} / \mathrm{ml}$ with a mean of $470 \mathrm{ng} / \mathrm{ml}(n=6)$ and was not lower than the mean concentration of $408 \mathrm{ng} / \mathrm{ml}$ (range 96-780, $n=3$ ) found at Day 22 or the $303 \mathrm{ng} / \mathrm{ml}$ calculated from the regression equation $\log y=0.201 x-1.941$ (where $y=$ concentration of oestrone sulphate and $x=$ length of gestation in days) for the change in plasma oestrone sulphate concentration during early pregnancy in the pig (Robertson et al., 1978).

\section{Anti-oestrogen titres in sow plasma}

Before the injection of antisera the sow plasma bound little $\left[{ }^{3} \mathrm{H}\right]$ oestradiol- $17 \beta$ and $\left[{ }^{3} \mathrm{H}\right]$ loestrone $(12 \%$ and $6 \%$ respectively). After starting the antibody treatment the mean percentage binding rose rapidly and appeared to plateau by Day 15 at $71 \%$ binding (Text-fig. 1 ). However, by increasing the amount of labelled oestrogens it was seen that in the plasma of one sow the concentration of antibodies in the plasma did not plateau but continued to rise (Text-fig. 2).

The excess unbound anti-oestrogen titre in the blood was capable of neutralizing 740,1500 and $3360 \mathrm{pg}$ oestrone/ml and 560,1120 and $2500 \mathrm{pg}$ oestradiol/ml at Days 12, 15 and 22 respectively.

\section{Embryos}

At slaughter on Day 22 all 6 sows possessed normally developing embryos. The mean \pm s.e.m. numbers of corpora lutea and embryos per sow were $22.2 \pm 2.9$ and $13.7 \pm 3.6$ respectively. The embryos had a mean \pm s.e.m. crown-rump length of $10.2 \pm 1.3 \mathrm{~mm}$.

\section{Histology}

When examined with the light microscope, the histological specimens from 3 of the 4 sows from which tissues were collected showed intimate attachment of the trophoblast to the maternal epithelium or remnants of the trophoblast along the maternal border, suggesting mechanical 


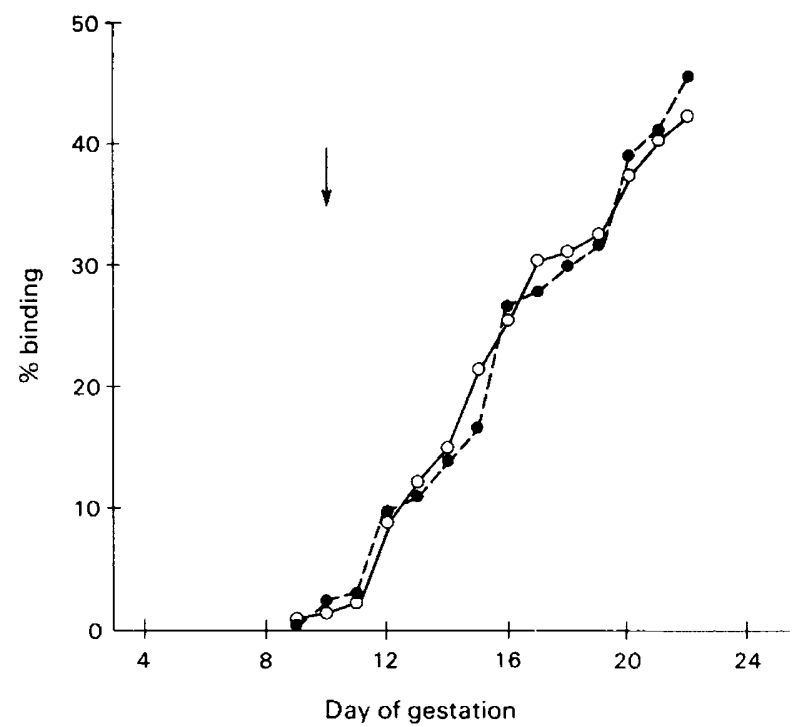

Text-fig. 2. The percentage binding of 70000 c.p.m. $\left[{ }^{3} \mathrm{H}\right]$ oestradiol-17及 (140 pg) (0) or $\left[{ }^{3} \mathrm{H}\right.$ ]oestrone $(187 \mathrm{pg})(\mathrm{O})$ to $25 \mu \mathrm{l}$ plasma from one sow before and after the start (arrow) of treatment with oestrogen antisera.

separation during sample preparation. The maternal blood vessels formed an almost continuous chain below the basal lamina and the epithelium was columnar with rounded apical projections and centrally located nuclei. Ultrastructural examination of a corpus luteum specimen from one of these sows revealed normal nuclei, mitochondria and a granular endoplasmic reticulum.

The single properly orientated specimen obtained from the 4 th animal presented a different appearance. The trophoblast was attached to the maternal component but the trophoblast cells showed a very lightly staining, foamy cytoplasm rather than the more homogeneous, less vacuolated matrix observed in other specimens. In addition, the basal borders of many trophoblast cells were often ruptured, possibly a mechanical artefact, but this had never been observed in previous material. Maternal blood vessels were very small and scarce while the epithelial cells were about half the normal height, darkly staining and the nuclei were pyknotic.

\section{Discussion}

It has been shown that the presence of embryos in the uterus of the sow at Day 12 will result in the prologation of luteal function (Niswender, Dziuk, Kaltenbach \& Norton, 1970), but the mechanism by which this transformation occurs is not known. Nor is it known to what extent, if any, hormones elaborated and secreted by the embryo are involved in the initiation of the process of attachment between the uterus and the conceptus.

Gardner, First \& Casida (1963) showed that oestradiol-17 $\beta$ and oestrone when injected daily into cyclic gilts from Day 11 of the cycle will induce prolongation of luteal function. They made the interesting finding that oestrone was more effective than oestradiol-17 $\beta$ in maintaining the weight of the corpus luteum. Goldenberg, Bridson \& Kohler (1972) found that oestrogens stimulated progesterone synthesis by porcine granulosa cells in culture, which suggests that the effect of oestrogens on the maintenance of the corpora lutea in the pig is mediated, at least in part, by a direct action on the luteal tissue. These observations, together with those of Perry $e t$ al. $(1973,1976)$ that the Day 12 pig blastocyst tissue synthesizes oestrogens in vitro, and those 
of Robertson \& King (1974) and Robertson et al. (1978) that oestrone sulphate arising from the uterus can be detected in maternal plasma by Day 16-17, suggested that embryonic oestrogens or their sulphoconjugates may be luteotrophic in the pig.

In the pregnant pig, apposition of the trophoblast and uterine epithelium is established by Day 15 and proceeds to attachment, with complete interdigitation of maternal and embryonic microvilli, during the 3rd and early 4th week of gestation (Crombie, 1972). Bulbous protuberances are prominent on the apical borders of maternal epithelium in unattached regions between Days 15 and 20, but these become shortened and rounded as attachment is established (Swift \& King, 1978). Maternal epithelial nuclei move from an apical to a central location as the attachment progresses and the blood vessels form an almost continuous chain below the basal lamina. Specimens from 3 of the 4 treated sows in the present study were assessed as normal or healthy when examined by light microscopy and compared with material previously collected from untreated animals. The unusual appearance observed in the 4th animal was possibly the result of early degeneration of this particular embryo rather than an effect of the treatment.

The treatment of pregnant sows with oestrogen antisera beginning on Day 10 does not affect the rescue of luteal function by the presence of embryos in the uterus or the initiation of placental attachment. The declining plasma level of progesterone that we observed after Day 13 was not due to the injection of oestrogen antisera because a similar pattern has been described in normal pregnant sows (Guthrie, Henricks \& Handlin, 1972; Robertson \& King, 1974). The number of developing embryos recovered at slaughter on Day 22 represents normal embryonic survival (see Perry \& Rowlands, 1962).

The present study has shown that the embryos continue to exert a luteotrophic effect even in the presence of excess antibodies to oestradiol-17 $\beta$ and to oestrone, indicating that unconjugated oestrogens present in the plasma of the sow are not luteotrophic. However, the findings do not rule out a luteotrophic action for the sulphoconjugates of embryonic oestrogens since the antisera used do not cross-react with these and luteal tissue has been shown to possess sulphatase activity (Perry et al., 1976). A local action of the unconjugated embryonic oestrogens on the endometrium to initiate placental attachment or to maintain luteal function by reducing prostaglandin production or by redirecting prostaglandin release is also possible (see Bazer \& Thatcher, 1977). Since the present evidence suggests that the embryo secretes unconjugated oestrogens which are then sulphated by the uterine endometrium and since there is no erosion of the maternal uterus during implantation in the pig, the question still remains whether or not the oestrogens diffusing from the lumen of the uterus through the epithelial cells of the endometrium are sulphated before or after they get into the capillary bed and are confronted by the antibodies to the unconjugated oestrogens. Since no decrease was found in the concentration of oestrone sulphate in the plasma this would indicate either that the unconjugated oestrogen is being sulphated before it gets into the capillary bed, and hence is not available for binding by the antibodies, or that the oestrone is in fact leaving the embryo as oestrone sulphate, as originally proposed by Robertson \& King (1974), and is absorbed as such through the endometrium.

The excellent technical assistance of R. Durnford and B. A. Atkinson is gratefully acknowledged. The paper is Animal Research Institute Contribution No. 836.

\section{References}

Anderson, D.M. \& Elsley, F.W.H. (1969) A note on the use of indwelling catheters in conscious adult pigs. $J$. agric. Sci., Camb. 72, 475-477.

Bazer, F.W. \& Thatcher, W.W. (1977) Theory of maternal recognition of pregnancy in the swine based on estrogen controlled endocrine versus exocrine secretion of prostaglandin $\mathrm{F}_{2 \alpha}$ by the uterine endometrium. Prostaglandins 14, 397-401.

Crombie, P.R. (1972) The morphology and ultrastructure of the pig's placenta throughout pregnancy. Ph.D. thesis, Cambridge University.

Gardner, M.L., First, N.L. \& Casida, L.E. (1963) Effect 
of exogenous estrogens on corpus luteum maintenance in gilts. J. Anim. Sci. 22, 132-134.

Goldenberg, R.L., Bridson, W.E. \& Kohler, P.O. (1972) Estrogen stimulation of progesterone synthesis by porcine granulosa cells in culture. Biochem. Biophys. Res. Commun. 48, 101-107.

Guthrie, H.D., Henricks, D.M. \& Handlin, D.L. (1972) Plasma estrogen, progesterone and luteinizing hormone prior to estrus and during early pregnancy in pigs. Endocrinology 91, 675-679.

King, G.J., Atkinson, B.A. \& Robertson, H.A. (1979) Development of the bovine placentome during the second month of gestation. J. Reprod. Fert. 55, 173180.

Neill, J.D., Johansson, E.D.G., Datta, J.K. \& Knobil, E. (1967) Relationship between the plasma levels of luteinizing hormone and progesterone during the normal menstrual cycle. J. clin. Endocr. Metab. 27, 1167-1173.

Niswender, G.D., Dziuk, P.J., Kaltenbach, C.C. \& Norton, H.W. (1970) Local effects of embryos and the uterus on corpora lutea in gilts. J. Anim. Sci. $\mathbf{3 0}$, $225-228$.

Perry, J.S. \& Rowlands, I.W. (1962) Early pregnancy in the pig. J. Reprod. Fert. 4, 175-188.

Perry, J.S., Heap, R.B. \& Amoroso, E.C. (1973) Steroid hormone production by pig blastocysts. Nature, Lond. 245, 45-47.
Perry, J.S., Heap, R.B., Burton, R.D. \& Gadsby, J.E. (1976) Endocrinology of the blastocyst and its role in the establishment of pregnancy. J. Reprod. Fert., Suppl. 25, 85-104.

Robertson, H.A. (1972) Sequential changes in plasma progesterone in the cow during the estrous cycle, pregnancy, at parturition, and post-partum. Can.J. Anim. Sci. 52, 645-658.

Robertson, H.A. \& King, G.J. (1974) Plasma concentration of progesterone, oestrone, oestradiol-17 $\beta$ and of oestrone sulphate in the pig at implantation, during pregnancy and at parturition. J. Reprod. Fert. 40, 133-141.

Robertson, H.A. \& Sarda, I.R. (1971) A very early pregnancy test for mammals: its application to the cow, ewe and sow. J. Endocr. 49, 407-419.

Robertson, H.A., Smeaton, T.C. \& Durnford, R. (1972) A method for the extraction, separation and estimation of unconjugated estrone, estradiol-17a and estradiol- $17 \beta$ in plasma. Steroids $20,651-667$.

Robertson, H.A., King, G.J. \& Dyck, G.W. (1978) The appearance of oestrone sulphate in the peripheral plasma of the pig early in pregnancy. J. Reprod. Fert. 52, 337-338.

Swift, P.L. \& King, G.J. (1978) Attachment of the trophoblast to uterine epithelium in the pig. Proc. 70th Meet. Am. Soc. Anim. Sci. p. 394, Abstr.

Received 30 March 1979 